\title{
Intravenous Administration is the Best Route of Mesenchymal Stem Cells Migration in Improving Liver Function Enzyme of Acute Liver Failure
}

\author{
Agung Putra ${ }^{1,2,3}$, Ika Rosdiana ${ }^{4}$, Dewi M. Darlan ${ }^{5}$, Iffan Alif ${ }^{1}$, Fitri Hayuningtyas ${ }^{6}$, Indriani Wijaya ${ }^{6}$, \\ Rita Aryanti ${ }^{1,3}$, Fadhli Rizal Makarim ${ }^{1,3}$, Arini Dewi Antari ${ }^{1,3}$ \\ ${ }^{1}$ Stem Cell and Cancer Research (SCCR), Medical Faculty, Sultan Agung Islamic University (UNISSULA), Semarang, Indonesia \\ ${ }^{2}$ Department of Postgraduate Biomedical Science, Medical Faculty, Sultan Agung Islamic University (UNISSULA), Semarang, Indonesia \\ ${ }^{3}$ Department of Pathological Anatomy, Medical Faculty, Sultan Agung Islamic University (UNISSULA), Semarang, Indonesia \\ ${ }^{4}$ Department of Rehabilitation Medicine, Medical Faculty, Sultan Agung Islamic University (UNISSULA), Semarang, Indonesia \\ ${ }^{5}$ Department of Parasitology, Faculty of Medicine, Universitas Sumatera Utara, Medan, Indonesia \\ ${ }^{6}$ Bachelor of Medical Science Program, Medical Faculty, Sultan Agung Islamic University (UNISSULA), Semarang, Indonesia
}

Corresponding author: Agung Putra, Stem Cell and Cancer Research (SCCR) Laboratory, Faculty of Medicine, Islamic Sultan Agung University, Semarang, Jl. Raya Kaligawe KM. 4 Semarang, Jawa Tengah 50112; E-mail: dr.agungptr@gmail.com; Tel.: +628164251646

Received: 23 Jan 2019 Accepted: 30 July $2019 \bullet$ Published: 31 March 2020

Citation: Putra A, Rosdiana I, Darlan DM, Alif I, Hayuningtyas F, Wijaya I, Aryanti R, Makarim FR, Antari AD. Intravenous administration is the best route of mesenchymal stem cells migration in improving liver function enzyme of acute liver failure. Folia Med (Plovdiv) 2020;62(1):52-8. doi: 10.3897/folmed.62.e47712.

\begin{abstract}
Background: Mesenchymal stem cells (MSCs) migrate and transmigrate to acute liver failure (ALF) area due to vascular endothelial growth factor (VEGF) stimulation as an attractant molecule then actively giving the paracrine signaling and or differentiating into primary hepatocytes, however the best route of MSCs transplanted to liver injury area remains unclear.

Aim: In this study we compare intravenous (IV) and intraperitoneal (IP) route of MSCs administration by analyzing serum glutamic pyruvic transaminase (SGPT), serum glutamic-oxaloacetic transaminase (SGOT) and bilirubin level as improvement markers of liver function and VEGF as attractant-proliferation molecule on days 2 and 5.
\end{abstract}

Materials and methods: Eighteen male Sprague-Dawley rats weighting $200 \mathrm{~g}$ were used in this study. They were divided in three study groups: vehicle control, IP and IV groups. The IV group was treated by MSCs at dose $1 \times 10^{6}$ by lateral tail vein injection and IP group received $1 \times 10^{6} \mathrm{MSC}$ via IP injection. The level of SGPT, SGOT and bilirubin were measured by an automatic analyzer, the VEGF level using enzyme-linked immunosorbent assay (ELISA), while the CD73 expression was evaluated using immunohistochemistry.

Results: This study showed that IV injection of MSCs was more efficient for increasing liver function than IP treatment group that confirmed by the observed significant decrease in SGPT, SGOT and bilirubin level on days 2 and 5 ( $\mathrm{p}<0.001)$. This effect was most likely mediated by the significant increase of VEGF level $(\mathrm{p}<0.05)$ on days 2 and 5.

Conclusion: Our result conclude that an IV administration of MSCs was more efficacious than the IP administration for liver injury regeneration.

\section{Keywords}

acute liver failure, intravenous, intraperitoneal, mesenchymal stem cells, vascular endothelial growth factor 


\section{INTRODUCTION}

Acute liver failure (ALF) is a life-threatening disease, characterized by massive hepatic necrosis of multiple lobes or acini and the infiltration of inflammatory cells, without pre-existing liver disease. ${ }^{1}$ The excessive inflammation and massive hepatocyte necrosis associated with ALF result in the sudden loss of liver function and multiple organ failure, which can lead to a high mortality rate. ${ }^{2}$ A previous study reported that liver tissue has the enormous regenerative potential to restore hepatocytes, even after most hepatocytes are completely lost ${ }^{3}$, through the activation of liver progenitor cell (LPC)-mediated regeneration, which can be derived from endogenous progenitor cells or bone marrow-derived circulating cells, particularly mesenchymal stem cells (MSCs). ${ }^{4}$ These findings suggested that MSCs play a role as an alternative cell source for the replacement of primary hepatocytes, in addition to immunoregulatory functions. Therefore, MSC transplantation could represent a promising strategy for liver regeneration during ALF. $^{5}$ However, the best route for the delivery of MSCs to liver injuries remains unclear.

MSCs are adult stem cells that are widely defined as plastic-adherent stromal cells, with multipotent differentiation capacity. MSCs naturally express various surface marker proteins, including CD73, CD90, CD105, CD44, and CD29, and lack the expression of other surface marker proteins, including CD45, CD34, CD14, CD11b, CD79a, CD19, and human leukocyte antigen (HLA) class II. Under standard in-vitro differentiation conditions, MSCs are able to differentiate into chondrocytes, osteocytes, adipocytes $^{6}$, and hepatocytes ${ }^{7}$. MSCs also have immunosuppressive properties, inhibiting the release of pro-inflammatory cytokines from several inflammatory cells, resulting in the transition into the proliferative phase. ${ }^{8}$ Improved liver function is characterized by decreased levels of biochemical markers, such as bilirubin, serum glutamic oxaloacetic transaminase (SGOT), and serum glutamic pyruvic transaminase (SGPT). ${ }^{9}$

Several studies have demonstrated that the intravenous (IV) delivery of MSCs may accelerate their homing to injury sites, including ALF areas, due to their immune-cell-like properties, which are also referred to as leukocyte-like. ${ }^{10,11}$ Under certain stimulation conditions, such as in the presence of stromal-derived factor (SDF-1), basic fibroblast growth factor (bFGF), and vascular endothelial growth factor (VEGF), MSCs may migrate and then transmigrate over the endothelial barrier to reach the target area. ${ }^{12}$ Other studies have indicated that VEGF appears to be particularly important in enhancing and directing MSC motility because CD44, an MSC marker protein, can also act as a co-receptor for VEGFR-2. ${ }^{13}$ Although IV injection is the most common technique used for the administration of MSCs for ALF treatments ${ }^{14}$, this method has several limitations, particularly the pulmonary "first-pass" effects that can cause the entrapment of cells in the lungs ${ }^{15}$. Another study showed the opposite results, demonstrating that in- traperitoneal (IP) administration was preferable to IV administration for the delivery of MSCs to the injury site. The IP technique provides a nutrient-rich and hemodynamically stable environment for isolated cells, including MSCs. ${ }^{16}$ These conflicting results indicate that the optimal route for MSCs administration to ensure their migration to the liver injury area remains unclear. The aim of this study was to determine the best route for the administration of MSCs for ALF treatments by analyzing serum glutamic pyruvic transaminase (SGPT), serum glutamic oxaloacetic transaminase (SGOT), and bilirubin levels, as serum markers of liver recovery, and VEGF levels, to represent homing molecules, both before and after the IP and IV administration of MSCs.

\section{MATERIALS AND METHODS}

\section{MSC isolation}

An umbilical cord was obtained from a healthy, 19-day pregnant rat (Sprague-Dawley), under deep anesthesia. After the blood vessel was removed, the umbilical cord was cut into pieces and transferred to a T25 culture flask, containing complete growth medium, which consists of Dulbecco's modified Eagle medium (DMEM, Sigma-Aldrich, Louis St, MO), containing 10\% fetal bovine serum (FBS, Gibco $^{\mathrm{Tm}}$ Invitrogen, NY, USA) and $100 \mathrm{IU} / \mathrm{ml}$ penicillin/ streptomycin. The cells were incubated in a humidified atmosphere, containing $5 \% \mathrm{CO} 2$, at $37^{\circ} \mathrm{C}$. The medium was changed every 3 days. When cells reached $80 \%$ confluence, the MSCs were passaged. Cells in their fourth passage were used for the following experiments.

\section{ALF animal model}

Eighteen male Sprague-Dawley (SD) rats, weighing 200 g, were housed in individually ventilated cages, with constant temperature $\left(22 \pm 2^{\circ} \mathrm{C}\right), 60 \%$ relative humidity, and a $12: 12$ hour light-dark cycle. Starting at 5 weeks old, rats were fed with standard food. To establish an animal model of ALF, all rats were induced by the IP injection of $0.1 \mathrm{~mL} / \mathrm{kg}$ carbon tetrachloride (CCl4, Sigma- Aldrich, Louis St, MO), dissolved in olive oil (1:1), 2 times per week, for 2 weeks.

\section{Flow cytometric immunophenotyping of MSCs}

To confirm the identity of MSCs, these cells were analyzed by flow at the fourth passage. Cell suspensions were incubated with fluorescein isothiocyanate (FITC)-conjugated, Allophycocyanin (APC)-conjugated, peridinin chlorophyll protein (PerCP)-Cy5.5-conjugated, and phycoerythrin (PE)-conjugated monoclonal antibodies, including antibodies against CD90, CD73, CD105, and Lin, for $30 \mathrm{~min}$, at $4^{\circ} \mathrm{C}$, in the dark. The analysis was performed using a BD 
PharmingenTM flow cytometer (BD Bioscience, Franklin Lakes, NJ, USA).

\section{In vitro differentiation}

We further performed an osteogenic differentiation assay at the fourth passage, to characterize the isolated cells. The MSCs were cultured in osteogenic induction medium, containing $50 \mu \mathrm{M} / \mathrm{L}$ ascorbate-2-phosphate, $10 \mathrm{mM} / \mathrm{L}$ $\beta$ glycerophosphate, $10-7 \mathrm{~mol} / \mathrm{L} / 0.1 \mu \mathrm{M}$ dexamethasone (Sigma-Aldrich, Louis St, MO), and 10\% FBS (Gibco ${ }^{\mathrm{Tm}}$ Invitrogen, NY, USA) in DMEM (Sigma-Aldrich, Louis St, $\mathrm{MO}$ ), at $37^{\circ} \mathrm{C}$ and $5 \% \mathrm{CO}_{2}$. To evaluate calcium deposition, the cells were fixed and stained with $0.2 \%$ Alizarin Red (Sigma-Aldrich Corp., St. Louis, MO, USA) (21 days).

\section{MSC administration}

Experimental rats were randomly assigned into two groups. The first group $(n=6)$ received $1 \times 10^{6}$ MSCs in $1 \mathrm{ml} \mathrm{NaCl}$ by lateral tail vein injection (IV). The second group $(n=6)$ received $1 \times 10^{6} \mathrm{MSC}$ in $1 \mathrm{ml} \mathrm{NaCl}$ by IP injection (IP).

\section{Liver functional enzyme assay}

SGOT, SGPT, and bilirubin were measured to determine liver function on days 0 (pre-treatment), 2, and 5. Blood samples were collected from the peri-orbital vein under anesthesia, using xylazine + ketamine $(5 \mathrm{mg} / \mathrm{kg}+100 \mathrm{mg} / \mathrm{kg}$ intramuscularly) (Alfasan, Netherlands). Serum levels of SGOT, SGPT, and bilirubin were measured using an automatic analyzer (BT 3000 PLUS, Italy).

\section{Enzyme-linked immunosorbent assay (ELISA)}

The serum levels of VEGF in both groups were measured using ELISA, according to the manufacturer's protocols (Fine Test, Wuhan, China). Serum levels were measured on days 0 (pre-treatment), 2, and 5, according to standard curves constructed for each assay. The colorimetric absor- bance was recorded at a wavelength of $450 \mathrm{~nm}$.

\section{MSC phenotyping in liver tissue}

The expression of MSCs in liver tissue was evaluated using immunohistochemistry techniques to detect MSC-positive markers. The liver tissue of each animal was fixed in $10 \%$ formaldehyde, embedded with paraffin, sectioned, and deparaffinized. We incubated the cells with a primary antibody against CD73, an MSC marker protein, according to a previously described protocol, and then observed the stained tissue under a microscope.

\section{Data Analysis}

The data are presented as the mean \pm standard deviation (SD). All calculations were performed using IBM SPSS 22.0 (IBM Corp., Armonk, NY, USA). Significant differences between groups were assessed by two-way analysis of variance (ANOVA) and Tukey's post hoc test. P values: ${ }^{\star} p<$ $0.05,{ }^{* *} p<0.001$.

\section{RESULTS}

\section{Characteristics of MSCs}

MSCs expressing specific markers were evaluated in Figure 1. The specific marker profiles for MSCs are CD73+, CD105+, CD90+, and Lin-, as described by the International Society of Cellular Therapy (ISCT). The results showed that UC-MSCs were 99.9\% CD90+, 95.9\% CD105+, 99.2\% CD73+, and 2.0\% Lin- (Fig. 1).

\section{MSC morphology and osteogenic differ- entiation}

The capacity of MSCs for plastic attachment was determined under standard culture conditions, in DMEM, supplemented with $10 \%$ FBS, $1 \%$ antibiotic, and $0.25 \%$
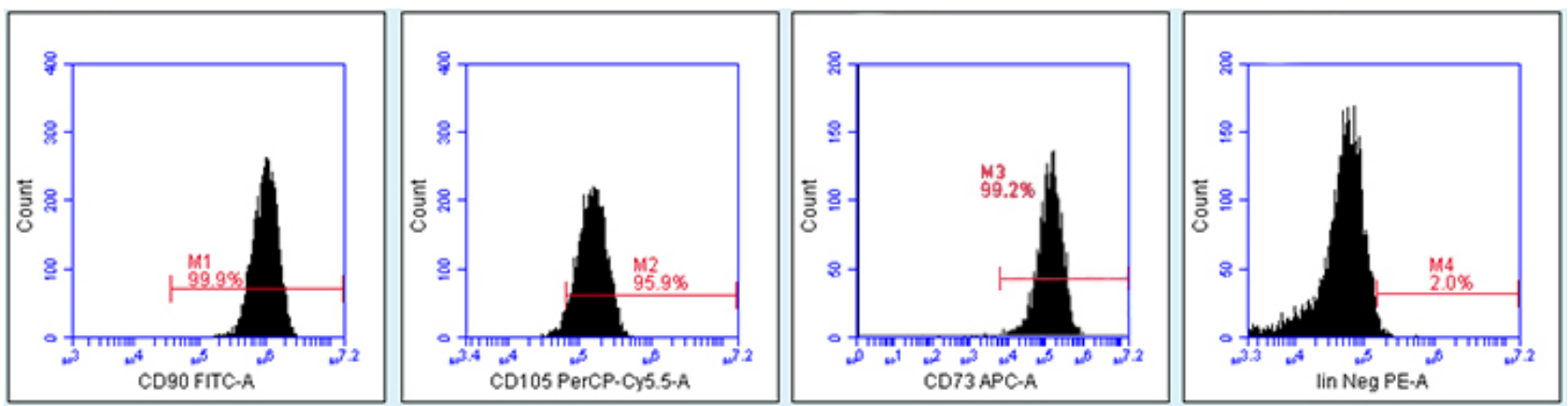

Figure 1. Flow cytometry characterization of UC-MSCs expressed CD90 (99.9\%), CD105 (95.9\%), CD73 (99.2\%) and Lin $(2.0 \%)$. 
fungizone. Cells exhibited spindle shapes and polygonal characteristics (Fig. 2a). Moreover, multilineage differentiation was achieved by culturing MSCs in osteogenic medium for 27 days (Fig. 2b).

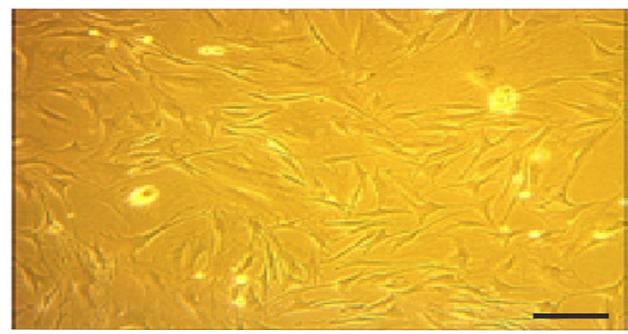

$2 a$ for bilirubin levels on days 2 and 5 .

\section{VEGF levels}

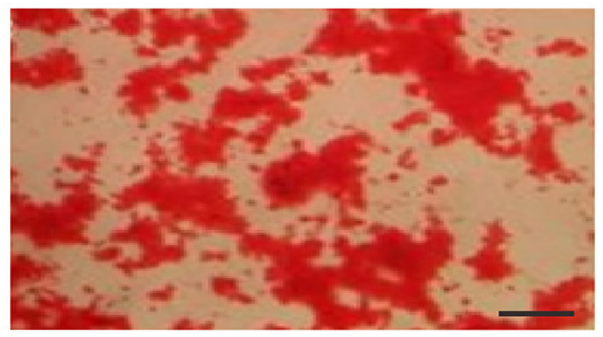

$2 b$

Figure 2. (a) In vitro culture of UC-MSC candidate showed spindle form of fibroblast-like cells, $\times 10$ magnification, (b) and the osteogenic differentiation test with osteogenic medium appears red color in MSC population (Alizarin Red Staining).

\section{MSC phenotyping in liver tissue}

The presence of MSCs in liver tissue was evaluated by the MSCs-positive marker CD73 using immunohistochemistry techniques and appeared as a brown color in cells as below (Fig. 3).

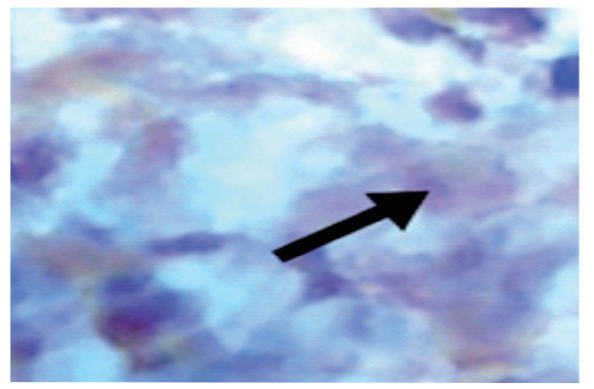

$3 a$
We examined VEGF levels using ELISA. VEGF concentrations significantly increased $(p<0.001)$ on days 2 and 5 compared with pre-treatment levels, and a significant difference $(p<0.001)$ was observed in VEGF concentrations between rats administered with MSCs via the IV and IP routes (Fig. 5). The results showed that rats that received IV

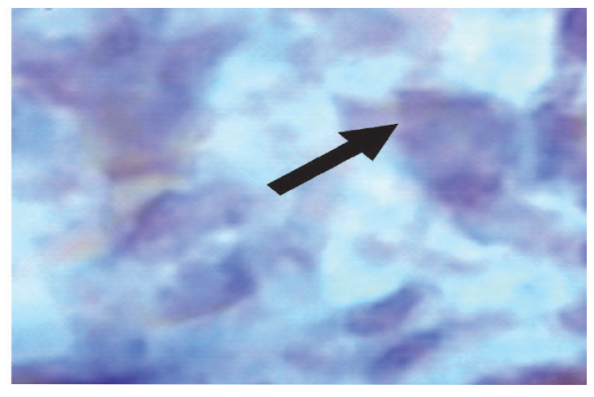

$3 b$

Figure 3. The expression of CD73 in liver tissue appeared as a brown color following (a) IV and (b) IP admninstration of MSCs, identified by an arrow.

\section{Liver function enzymes}

We measured the levels of SGPT, SGOT, and bilirubin on days 2 and 5, using an automatic analyzer. The levels of SGPT, SGOT, and bilirubin decreased significantly on days $2(\mathrm{P}<0.05, \mathrm{P}<0.001$, and $\mathrm{P}<0.001$, respectively) and 5 ( $\mathrm{P}$ $<0.001)$ following the injection of MSCs for all treatments of ALF rat models (Fig. 4). On both days 2 and 5, the IV treatment showed the lowest levels of SGPT $(87.80 \mu / \mathrm{L}$ and $52.40 \mu / \mathrm{L}$, respectively) and SGOT $(155.20 \mu / \mathrm{L}$ and 105.80 $\mu / \mathrm{L}$, respectively). The IV group was significantly more effective than the vehicle group $(\mathrm{P}<0.001)$ with regards to the SGPT and SGOT levels. In addition, the IV group had a greater effect than the IP group on the SGPT level on day 5 and on the SGOT level on both days 2 and $5(\mathrm{P}<0.05)$. No significant difference was observed among all treatments treatments had the highest VEGF levels on days 2 (110.11 $\mathrm{pg} / \mathrm{mL})$ and $5(101.31 \mathrm{pg} / \mathrm{mL})$. The VEGF levels were increased more effectively in the IV group than in the IP group $(\mathrm{P}<0.001)$, on both days 2 and 5 .

\section{DISCUSSION}

ALF is a devastating syndrome that results in the sudden loss of hepatic cells and/or cellular function, leading to organ failure and death. ${ }^{17}$ The necrosis of liver cells during ALF is dramatic and progressive, and the time between the development of initial symptoms and death can be very short. ${ }^{18}$ Thus, new treatment approaches that focus on liver regeneration would provide great clinical value. ${ }^{19}$ To delineate the homing mechanisms of MSCs during the regener- 


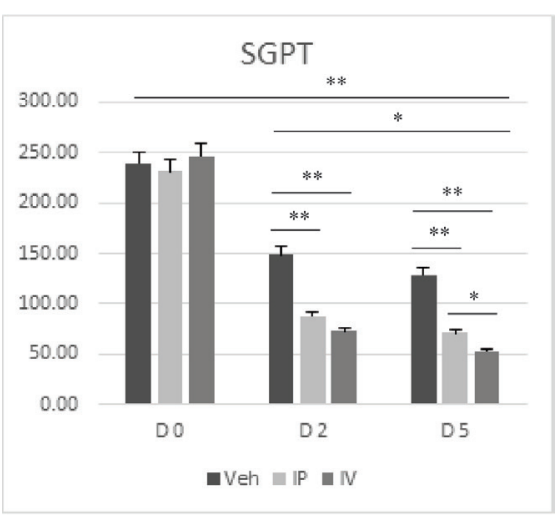

$4 a$

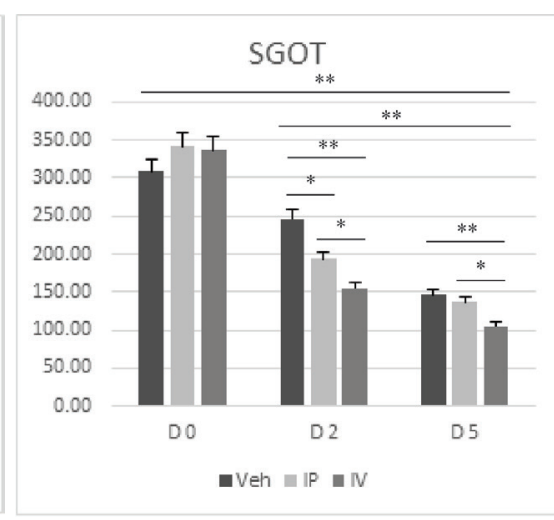

4b

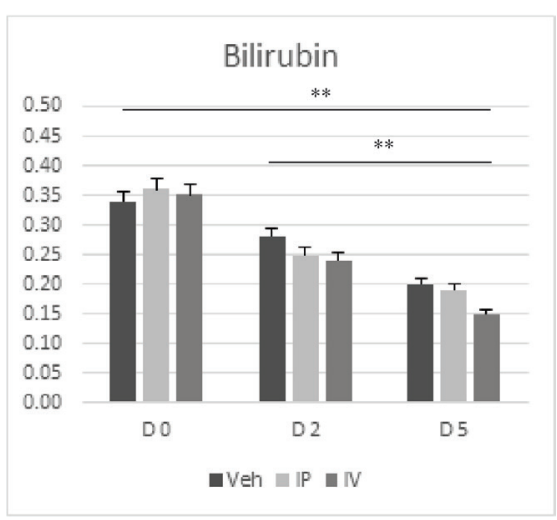

$4 c$

Figure 4. MSCs treatment decrease the level of (a) SGPT (b) SGOT and (c) bilirubin in all treatments. On day 2, the IV treatment showed the lowest level SGPT and SGOT $(87.80$ and $155.20 \mathrm{u} / \mathrm{L})$ as well as on day $5(52.40$ and $105.80 \mathrm{u} / \mathrm{L}) .{ }^{\star} p<0.05,{ }^{* *} p<0.001$.

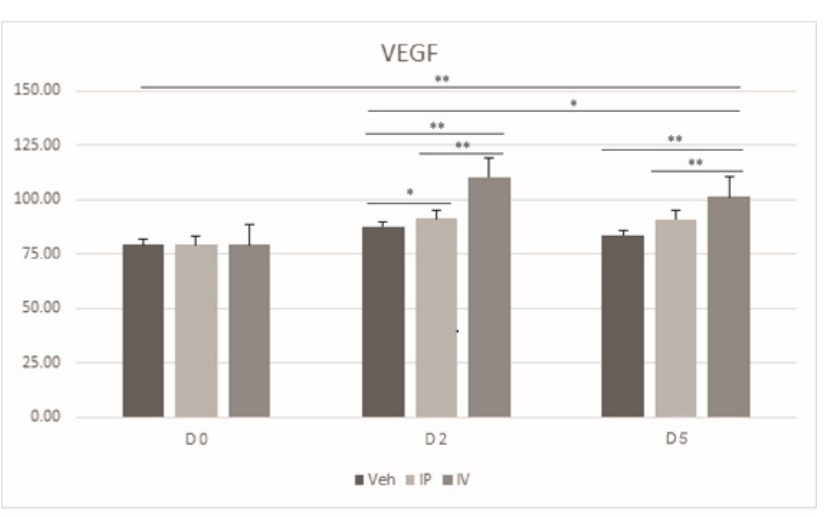

Figure 5. ELISA assay showed IV treatments have the highest VEGF level on days 2 and $5(110.11$ and $101.31 \mathrm{pg} / \mathrm{mL}),{ }^{\star} p<0.05$, ${ }^{* *} p<0.001$.

ation of liver injuries, animal models with CCL4-induced liver injuries have been used to imitate human ALF disease. ${ }^{2,20}$ CCL4 was used in our study to induce ALF in a rat model, as described by previous protocols. ${ }^{9}$ In this study, we injected MSCs into ALF rat models, through the IP and IV routes.

We found that the level of SGPT and SGOT on days 2 and 5 significantly decreased compared with those on day 0 (pre-treatment) for both treatment groups. We also found significant differences in the SGPT and SGOT levels between rats treated with IV and IP injections, and IV injections appeared to be more efficacious than IP injections, based on the expression of CD73, an MSC marker, in the liver tissue (Fig. 3). This result was in line with the observed significant increase in VEGF levels on days 2 and 5. Our findings suggested that IV injections of MSCs are more efficient for ALF regenerative processes than the IP route and that the migration of MSCs to the liver injury correlated with VEGF levels. MSCs have the ability to control inflammation by suppressing activated inflammatory cells and accelerating the transition of inflammation to the proliferation phase. $^{21}$
We hypothesize that MSCs administration by IV injection have the ability to migrate to injured areas more quickly than those administered through then IP route, due to the leukocyte-like properties of MSCs. ${ }^{10,11}$ Injured cells release hypoxia-inducible factor (HIF)-1a, which acts as a stabilizer and activator molecule for the release of chemoattractant signals, such as SDF-1, hepatocyte growth factor (HGF), and VEGF. ${ }^{22}$ MSCs respond to these chemoattractant signals by expressing CD44, which acts as an adhesion molecule for cell-cell and cell-substrate interactions, in addition to VLA-4, CXCR-4, and cMet. ${ }^{23}$ Specifically, in MSCs, CD44 acts as a co-receptor for VEGFR-2 ${ }^{13}$ and activates the CD44-Src-integrin signaling axis ${ }^{24}$. These signals may initiate the homing of MSCs to injured areas by triggering CD44-VEGF and VLA-4-VCAM-1 binding in capillary endothelial cells, facilitating the transmigration to injured areas (Fig. 6). MSCs in the injured area suppress the activation of resident inflammation cells, particularly activated macrophages, through the release of prostaglandin E2 (PGE2), TSG 6, interleukin (IL)-10, transforming growth factor (TGF)- $\beta$, and IL-1ra. ${ }^{21,25}$ The regulation of the inflammatory process may result in the initiation of the regeneration phase, which is characterized by the increased expression of several proliferation molecules, such as VEGF and platelet-derived growth factor (PDGF). ${ }^{26} \mathrm{VEGF}$ levels correlated with the acceleration of liver function re-

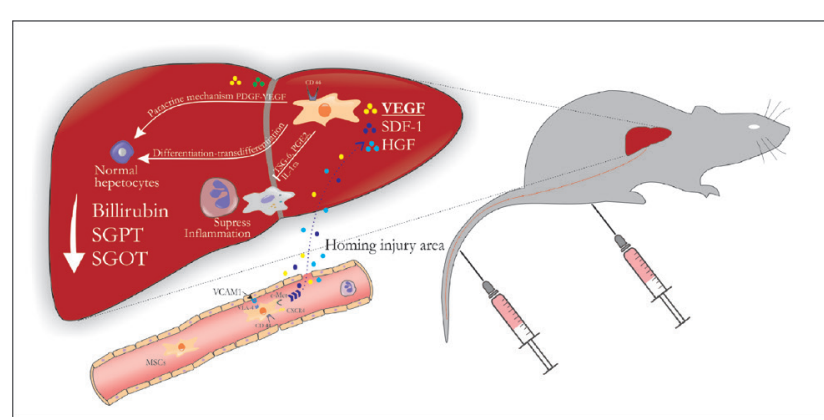

Figure 6. Schematic for MSCs homing in intravenous administration in rats. 
pair, as characterized by the significant decreases in SGPT and SGOT levels.

The transplantation of MSCs through IV injections may also inhibit hepatocyte death and increase hepatocyte survival in the ALF rat model. ${ }^{27}$ Another study showed increasing VEGF levels following the IV administration of MSCs to injured tissues, followed by improved angiogenesis, including vascular necrosis. ${ }^{28}$ Our study showed that the administration of MSCs through IV injection was more efficacious than those administered through the IP route in ALF model rats. We hypothesize that MSCs respond to a homing mechanism that attracts them to injured areas, which corresponds with an increase in VEGF levels. However, in our studies, we did not analyze the concentrations of SDF-1, CXCR-4 or HGF, which may act as additional chemoattractant molecules during the homing process; thus, the detailed mechanism associated with the homing of MSCs to injured areas remains unclear.

\section{CONCLUSION}

In this study, we concluded that the IV administration of MSCs was more efficacious than the IP administration of MSCs for ALF treatment. This study provided new insight into the benefits of the IV administration of MSCs and encourages the clinical application of IV-injected MSCs for injured tissues, particularly ALF.

\section{ACKNOWLEDGMENTS}

We would like to thanks the Stem Cell and Cancer Research Laboratory, Medical Faculty, Universitas Islam Sultan Agung, Semarang for making all facilities available to finish this research.

\section{Conflict of Interest}

The authors report no conflicts of interest. The authors are responsible for the content and writing of this article.

\section{REFERENCES}

1. Lee WM. Acute liver failure. SeminRespir Crit Care Med 2012; 33(1): 36-45.

2. Wang DW, Yin YM, Yao YM. Advances in the management of acute liver failure. World J Gastroenterol 2013; 19(41): 7069-77.

3. Kholodenko IV, Yarygin KN. Cellular mechanisms of liver regeneration and cell-based therapies of liver diseases. Biomed Res Int 2017; 2017: 8910821.

4. Itoh T, Miyajima A. Liver regeneration by stem/progenitor cells. Hepatology 2014; 59(4): 1617-26.

5. Zhou X, Cui L, Zhou X, et al. Induction of hepatocyte-like cells from human umbilical cord-derived mesenchymal stem cells by defined microRNAs. J Cell Mol Med 2016; 21(5): 881-93.

6. Ullah I, Subbarao RB, Rho GJ. Human mesenchymal stem cells - current trends and future prospective. Biosci Rep 2015; 35(2): e00191.
7. Chivu M, Dima SO, Stancu CI, et al. In vitro hepatic differentiation of human bone marrow mesenchymal stem cells under differential exposure to liver-specific factors. Transl Res 2009; 154(3):122-32.

8. Kocabayoglu P, Lade A, Lee YA, et al. $\beta$-PDGF receptor expressed by hepatic stellate cells regulates fibrosis in murine liver injury, but not carcinogenesis. J Hepatol 2015; 63(1): 141-7.

9. Zhou R, Li Z, He C, et al. Human umbilical cord mesenchymal stem cells and derived hepatocyte-like cells exhibit similar therapeutic effects on an acute liver failure mouse model. PLOS ONE 2014; 9(8): e104392.

10. Yagi $\mathrm{H}$, et al. Mesenchymal stem cells: mechanisms of immunomodulation and homing. Cell Transplant 2010; 19(6): 667-79.

11. Sohni A, Verfaillie CM. Mesenchymal stem cells migration homing and tracking. Stem Cells Int 2013; 2013: 130763.

12. Wang R, Liu W, Du M, et al. The differential effect of basic fibroblast growth factor and stromal cell-derived factor-1 pretreatment on bone morrow mesenchymal stem cells osteogenic differentiation potency. Mol Med Rep 2017; 17(3): 3715-21.

13. Aldridge V, Garg A, Davies N, et al. Human mesenchymal stem cells are recruited to injured liver in a $\beta 1$-integrin and CD44 dependent manner. Hepatology 2012: 56(3); 1063-73.

14. Kean TJ, Lin P, Caplan AI, et al. MSCs: delivery routes and engraftment, cell-targeting strategies, and immune modulation. Stem Cells International 2013; 2013: 732742.

15. Fischer UM, Harting MT, Jimenez F, et al. Pulmonary passage is a major obstacle for intravenous stem cell delivery: the pulmonary firstpass effect. Stem Cells Dev 2009; 18(5): 683-92.

16. Wang $\mathrm{M}$, Liang $\mathrm{C}, \mathrm{Hu} \mathrm{H}$, et al. Intraperitoneal injection (IP), intravenous injection (IV) or anal injection (AI)? Best way for mesenchymal stem cells transplantation for colitis. Scientific Reports 2016; 6(5):1-13.

17. Sun L, Fan X, Zhang L, et al. Bone mesenchymal stem cell transplantation via four routes for the treatment of acute liver failure in rats. Int J Mol Med 2014; 34(4): 987-96.

18. Weng HL, Cai X, Yuan X, et al. Two sides of one coin: massive hepatic necrosis and progenitor cell-mediated regeneration in acute liver failure. Front Physiol 2015; 6: 178.

19. Detry O, Vandermeulen M, Delbouille MH, et al. Infusion of mesenchymal stromal cells after deceased liver transplantation: A phase I-II, open-label, clinical study. J Hepatol 2017; 67(1): 47-55.

20. Zhou X, Cui L, Zhou X, et al. Induction of hepatocyte-like cells from human umbilical cord-derived mesenchymal stem cells by defined microRNAs. J Cell Mol Med 2016; 21(5): 881-93.

21. Prockop DJ, Youn Oh J. Mesenchymal stem/stromal cells (MSCs): Role as guardians of inflammation. Molecular Therapy 2012; 20(1): 14-20.

22. Lin $\mathrm{W}, \mathrm{Xu} \mathrm{L}, \mathrm{Zwingenberger} \mathrm{S,} \mathrm{et} \mathrm{al.} \mathrm{Mesenchymal} \mathrm{stem} \mathrm{cells} \mathrm{homing}$ to improve bone healing. J Orthop Translat 2017; 9: 19-27.

23. Marquez-Curtis LA, Janowska-Wieczorek A. Enhancing the migration ability of mesenchymal stromal cells by targeting the SDF-1/ CXCR4 axis. BioMed Research International 2013; 2013: 561098.

24. Tremmel M, Matzke A, Albrecht I, et al. A CD44v6 peptide reveals a role of CD44 in VEGFR-2 signaling and angiogenesis. Blood 2009; 114: 5236-44.

25. Putra A, Ridwan F, Putridewi A, et al. The role of TNF- $\alpha$ induced MSCs on suppressive inflammation by increasing TGF- $\beta$ and IL-10. Open Access Maced J Med Sci 2018; 6(10): 1779-83.

26. Landén NX, Li D, Ståhle M. Transition from inflammation to proliferation: a critical step during wound healing. Cell Mol Life Sci 2016; 73(20): 3861-85

27. Wang $\mathrm{YH}, \mathrm{Wu} \mathrm{DB}$, Chen B, et al. Progress in mesenchymal stem cell-based therapy for acute liver failure. Stem Cell Res Ther 2018; 9(1): 227.

28. Eirin A, Lerman LO. Mesenchymal stem cell treatment for chronic renal failure. Stem Cell Res Ther 2014; 5(4): 83. 


\title{
Внутривенное введение является лучшим путём для миграции мезенхимальных стволовых клеток для улучшения функции печени при острой печёночной недостаточности
}

\author{
Агунг Путра ${ }^{1,2,3}$, Ика Росдиана ${ }^{4}$, Деуи М. Дарлан ${ }^{5}$, Ифан Алиф ${ }^{1}$, Фитри Хаюнингтияс ${ }^{6}$, \\ Индриани Уиджая ${ }^{6}$, Рита Ариянти ${ }^{1,3}$, Фадхли Ризал Макарим ${ }^{1,3}$, Арини Деуи Антари ${ }^{1,3}$ \\ 1 Лаборатория исследования стволовых клеток и рака (ИСКР), Медицинский факультет, Исламский университет Султан Агунг \\ (UNISSULA), Семаранг, Индонезия \\ ${ }^{2}$ Кафедра последидпломного образования в области биомедицинскхи наук, Медицинский факультет, Исламский университет Султан Агунг \\ (UNISSULA), Семаранг, Индонезия \\ ${ }^{3}$ Каферда патологической анатомии, Медицинский факультет, Исламский университет Султан Агунг (UNISSULA), Семаранг, Индонезия \\ ${ }^{4}$ Кафедра реабилитационной медицины, Медииинский факультет, Исламский университет Султан Aгунг (UNISSULA), Семаранг, Индонезия \\ ${ }^{5}$ Кафедра паразитологии, Медицинский факультет, Университет „Суматера Утара”, Медан, Индонезия \\ ${ }^{6}$ Бакалавр медицинских наук, Медицинский бакультет, Исламский университет Султан Агунг(UNISSULA), Семаранг, Индонезия
}

Адрес для корреспонденции: Агунг Путра, Лаборатория исследования стволовых клеток и рака (ИСКР), Медицинский факультет, Исламский университет Султан Агунг (UNISSULA), ул. „Рая Калигауе” КМ. 4 ,Семаранг, Джауа Тенгах 50112; E-mail: dr.agungptr@gmail.com; Тел.: +628164251646

Дата получения: 23 января 2019 Дата приемки: 30 июля 2019 Дата публикации: 31 марта 2020

Образец цитирования: Putra A, Rosdiana I, Darlan DM, Alif I, Hayuningtyas F, Wijaya I, Aryanti R, Makarim FR, Antari AD. Intravenous administration is the best route of mesenchymal stem cells migration in improving liver function enzyme of acute liver failure. Folia Med (Plovdiv) 2020;62(1):52-8. doi: 10.3897/folmed.62.e47712.

\section{Абстракт}

Введение: Мезенхимальные стволовые клетки мигрируют и трансмигрируют в область печёночной недостаточности, чтобы стимулировать сосудистый эндотелиальный фактор роста, каким является фактор аттрактантных молекул, а затем активно передают паракринную сигнализацию и / или дифференцируются в первичные гепатоциты. Однако лучший путь для трансплантации мезенхимальных стволовых клеток, трансплантированных для миграции в область печёночной недостаточности, остаётся невыясненным.

Цель: В этом исследовании мы сравниваем внутривенный и внутрибрюшинный пути введения мезенхимальных стволовых клеток с помощью анализа сывороточной глутаминовой пировиноградной трансаминазы, сывороточной глутамино-оксалоуксусной трансаминазы и билирубина в качестве маркеров улучшения функции печени и сосудистого эндотелиального фактора роста в качестве аттрактантной молекулы пролиферации в дни 2 и 5.

Материалы и методы: В этом исследовании использовали 18 самцов крыс Sprague-Dawley. Они были разделены на три группы: контрольную, внутрибрюшинного введения и внутривенного введения. Первой группе вводили $1 \times 106$ мезенхимальных стволовых клеток путём внутривенной инъекции в хвостовую вену, а второй группе вводили $1 \times 106$ мезенхимальных стволовых клеток путём внутрибрюшинной инъекции. Уровни сывороточной глутаминовой пировиноградной трансаминазы, сывороточной глутамино-оксалоуксусной трансаминазы и билирубина были измерены с использованием автоматического анализатора, в то время как уровень сосудистого эндотелиального фактора роста был исследован с помощью иммуноферментного анализа.

Результаты: Это исследование показало, что внутривенный путь был более эффективным, чем внутрибрюшинный, с улучшением функции печени, сопровождаемым значительным снижением сывороточной глутаминовой пировиноградной трансаминазы, сывороточной глутамино-оксалоуксусной трансаминазы и билирубина в дни 2 и 5 (р <0,001). Этот эффект, скорее всего, был обусловлен значительным увеличением уровня сосудистого эндотелиального фактора роста (р <0,05) в дни 2 и 5.

Выводы: Наши результаты показывают, что внутривенная инъекция является лучшим путём для восстановления функции печени.

\section{Ключевые слова:}

острая печёночная недостаточность, внутривенный, внутрибрюшинный, мезенхимальные стволовые клетки, сосудистый эндотелиальный фактор роста 